\title{
The Dramatization and Embodiment of God of the Wilderness
}

\author{
Isabel Mukonyora
}

This chapter marks the first hundred years of the Johane Masowe Apostles Church with something long overdue - a study of theological ideas found in a collection of sacred texts called the Gospel of God. ${ }^{1}$ These texts tell stories about the founder of the Masowe Apostles, Johane Masowe, the pillar of a church inspired by stories from the Bible. For instance, the stories about Moses acting as the leader of the people of God - victims of oppression who wander in the wilderness in Exodus - explains the ritual behavior of Masowe Apostles and migration from Zimbabwe to Botswana, South Africa, Mozambique, Zambia, Malawi, Tanzania, Kenya, and beyond. ${ }^{2}$ Since the 1930s, Masowe Apostles have also walked towards the fringes of cityscapes to give expression to the same quest for liberation in Zimbabwe, and wherever else in the world that the problems of life on earth have turned Masowe Apostles into believers inspired by the idea of wilderness to reach out to God. Today, Masowe Apostles are known to travel far and wide, starting with the continent of Africa, and, they are even more well-known for dressing in white robes and going outdoors to pray for salvation.

As shown below, additional stories about John the Baptist and Jesus talking about salvation in the outskirts of the City of Jerusalem also inspired the development of a lived understanding of the New Testament Masowe Apostolic theology as to express in terms of oral tradition of faith. Anyone who reads the Gospel of God after reading this chapter should be able to see that the sacred texts were produced in an attempt to textualize an oral tradition of Christianity

1 The Gospel of God is the appendix to Clive Dillon-Malone, The Korsten Basketmakers: A study of the Masowe Apostles, an indigenous African Religious Movement (Manchester: Manchester University Press, 1978), 138-145.

2 Nowadays, Masowe Apostles can be found in big cities in England and North America. I have suggested that we start looking at wandering in the wilderness as symbolic language for addressing questions about God. See Isabel Mukonyora, "Women of the African Diaspora Within: The Masowe Apostles, an African Initiated Church," in Women and Religion in the African Diaspora: Knowledge, Power and Performance, eds. R. Marie Griffith and Barbara D. Savage (Baltimore: The Johns Hopkins Press, 2006), 59-80. 
in which the scriptures inspired strong beliefs in a God whose presence can be experienced on earth. ${ }^{3}$ Clive Dillon-Malone, the anthropologist who compiled The Gospel of God with some of the immediate followers of Johane Masowe led to this inquiry allowing the author to test the suggestion that Masowe Apostles developed a distinctly African lived theology.

The aim of this chapter, therefore, is to show how theology is being done by people who dramatize, embody, and/or perform their knowledge about God. For instance, instead of reading stories about Moses, John the Baptist and Jesus wandering in the wilderness as described in the Scriptures, Masowe Apostles ground it in their ritual behavior. For example, by walking to the outskirts of the city of Harare, removing their shoes and spending four to six hours praying on the dirt with the sun shining and the wind blowing, they perform their knowledge of God. The term sowe is used to describe the sacred places used for prayer, which can be on the edge of a golf course, small forests, or dry meadows - wherever there is unoccupied land with which to give expression to the idea of children of God on the margins of society. Masowe Apostles are theologians of liberation whose understanding of God is thus lived, dramatized, and embodied. There is a lot to learn about lived Christianity from this ritual behavior, especially as it draws attention to Mother Earth whose elements of nature also tell us something about human suffering in the world. ${ }^{4}$

The Gospel of God is looked at in this article on Masowe theology because it gives meaning to the lived conceptualization of God by the founder of the Masowe Apostles. This booklet consists of stories about the birth of Johane Masowe, somewhere between 1914 and 1915, his difficult youth in a colonial homeland called Gandanzara (Land of Hunger), near death experiences caused by severe headaches, and conversion experiences associated with his healing and ministry to serve fellow African children of God as their wandering messenger of the hope for healing and salvation. Although most people take it for granted that Masowe Apostles dress in white robes and go to pray in the margins of Africa's cityscapes, this oral tradition of Christianity would not exist without the founder turning his own experiences of reality into a story telling us something about the meaning and purpose of God among victims of colonial oppression, the poor and sick. Briefly, Johane Masowe's own journey left behind thousands of followers in southern, central and east Africa because he became the prophet setting an example by "wandering in the wilderness"

3 Matthew Engelke, A Problem of Presence: Beyond Scripture in an African Church. (Berkeley: University of California Press, 2007).

4 Sallie McFague, A New Climate for Theology: God, the World, and Global Warming (Minneapolis: Fortress Press, 2008). 
until his death in 1978. ${ }^{5}$ Today, Johane is the prophet and founder of one of the most studied popular African Initiated Churches (AICs) originating among the Shona in Zimbabwe. As the anthropologist Matthew Engelke found in his book, A Problem of Presence, about a separate church called the Masowe we Chishanu Apostles, such is the power of the oral tradition of Christianity among the Masowe Apostles, they take us beyond the Scriptures by making their knowledge of God live and direct. What Engelke is saying is that the Judeo-Christian Bible has a place among the Masowe Apostles although the Word of God must be "live and direct from the Holy Spirit," that is, something performed or dramatized by the believer. ${ }^{6}$ Theologians must be more aware, therefore, of the need for humans to practice their faith and, furthermore, to learn to do so from dramatizations of knowledge about God as it becomes embodied and engages the believer through prayer.

Cited throughout this chapter is a "thick description" of Christianity for theologians, social scientists, and scholars publishing works on the anthropology of Christianity in Africa. The working definition of religion provided by the anthropologist Clifford Geertz is useful to note because he writes that it is

(1) a system of symbols (2) which acts to establish powerful, pervasive and long-lasting moods and motivations in humans. (3) by formulating conceptions of a general order of existence and (4) clothing these conceptions with such an aura of factuality that (5) the moods and motivations seem uniquely realistic. ${ }^{7}$

Masowe Apostles not only dress in white linen, they face east to pray, remove their shoes on sacred ground, which they call masowe (the sacred wilderness), and insist on speaking in Shona at prayer. They go outdoors so that the didactic function of the message of the gospel centered on images of human suffering "has an aura of factuality" in Geertz's terms. ${ }^{8}$

In this case study on Masowe Apostolic theology, old narratives about God and human beings hoping for redemption become meaningful through

5 "Gospel of God." Johane was in his early 20 when he started preaching.

6 Engelke, A Problem of Presence. See Introduction, 1-45.

7 Clifford Geertz, Interpretation of Cultures (New Work: Basic Books, 1973), 90.

8 Ibid. 
symbolic acts of prayer that go on for anything from five to six hours at weekends, and occasionally all night long. Rather like liberation theologians draw attention to concrete social problems of oppression and climate change, ${ }^{9}$ Masowe Apostles draw attention to the serious problems of colonial and postcolonial oppression, industrialization, and urbanization as the historic roots of the ecological destruction of human and other forms of planetary life. As reflected in discussions of the Masowe understanding of the concept, God is a voice speaking to individuals through their conscience about self-empowerment, caring, sharing, healing, and generally giving all believers hope for salvation. ${ }^{10}$

As hinted above the Gospel of God is an African narrative about the Exodus, and New Testament sources for the knowledge of God which Johane Masowe developed in terms of a religious understanding of himself as a prophet addressing African experiences of colonialism and, as he traveled north of Zimbabwe into Zambia, post-colonial violence, much sickness, and poverty.11 Although cited throughout this chapter, one does not hear much about the Gospel of God in dramatizations of faith among Masowe Apostles. In fact, the emergence of an African orthodoxy for the wilderness church is very important, but not the starting point for the study of a lived conceptualization of God in which reading sacred texts and doing hermeneutics are replaced by ritual behavior. After all, the Shona culture underpinning the church was, until the colonial era, sustained by a spirituality based on an oral tradition made up of ngano, folklore with a special focus on social values and ethics, songs about existential problems of life on earth, rhythmic dance, and thoughtful prayer at ancestral ceremonies for the sick and dead. In the writing of the Gospel of God, the New Testament was used, rather like folklore, as a source of knowledge for a Shona-speaking messenger from God to vanhu vatema (black people) who shared his feelings of marginality, hope for liberation, and ultimately the salvation promised to Christians after death. ${ }^{12}$

In fact, the Masowe Apostles encountered during my anthropological research in the margins of Harare viewed the Bible as an old book telling stories about God's revelation to believers from the ancient past. When I asked

9 Pope Francis, Laudato Si: On Care for Our Common Home, Encyclical Letter, 2015.

10 The conclusion is reached by watching Masowe Apostles pray in the sacred wilderness. "National Public Radio interview with Krista Tippett": http://www.onbeing.org/program/ sacred-wilderness-african-story/169/audio - February 22, 2007.

11 By the time Johane Masowe died, the AIDs pandemic was growing on the continent of Africa.

12 Isabel Mukonyora, "The dramatization of Life and Death by Johane Masowe," Zambezia 25, no. 2 (1998): 191-207. 
questions about the old Bible, the answer was always that it refers to lived theologies of children of God in the past. When it comes today, we know it is the same eternal God because Masowe Apostles are prompted to do what they do, Him speaking to the conscience. Going to pray on the margins of the cityscapes from which Masowe Apostles migrate on the continent and beyond thus comes naturally to all the children of God. ${ }^{13}$ When it comes to lived theology, what is more important is the African oral tradition of Christianity - a means of communicating certain fundamental principles of life, social values, and ethics for direct consideration. ${ }^{14}$

It is time to see if, almost a hundred years later, Masowe Apostles still have a lived theology of liberation for vanhu vatema (black people) and to examine the forms it takes in the wilderness of African cities still faced by problems of oppression and violence, the AIDS pandemic, poverty, and climate change. ${ }^{15}$ Whilst the methods of inquiry used by liberation theologians draw attention to life through critical reflection on society, Masowe Apostles have created a rich pool of culturally appropriate religious terms, images, and symbolic actions which correspond with "the live and direct" knowledge of a God of the poor and sick. ${ }^{16}$

As a result, this theological inquiry is rooted in human behavior. The popular definition of religion by Clifford Geertz (1926-2006) cited above is used in this chapter because, for almost a century, Masowe Apostles have dramatized their theology by walking across dry marshes, small forests, rivers, lakes, the edges of golf courses, and the spaces behind shopping centers to spend, on average, whole mornings or afternoons embodying their understanding of the God they associate with the gift of the Holy Spirit: making a mental connection with a biblical past in which images of the wilderness are used to reveal deep

13 I have an anonymous recording of Masowe Apostles traveling from the Johane Masowe headquarters in Nairobi, Kenya, to spread their gospel among the poor in India. I also have emails from London, Manchester, and California from individuals trying to establish if I am a practicing member of their global church. It is also possible to find websites on Masowe Apostles living in the West.

14 Ngano were usually told regularly by the fire in Shona homes. Whenever there was a special point to note, the participants would respond by saying dzepfunde - "we agree with this wisdom."

15 The first sign of Masowe Apostles and groups of African Christians who decided to start their own lived theology of liberation through schism are white robes and outdoor worship in the masowe or sacred wilderness.

16 Liberation theology opens the door to sociological and political issues that influence the lived understanding of God among the poor, see Gustavo Gutiérrez, A Theology of Liberation: History, Politics and Salvation, trans. Caridad Inda and John Eagleson (Maryknoll, NY: Orbis Books, 1988). 
emotions to do with the need for healing minds, bodies, and souls on a quest for God the creator. Images of John the Baptist, Jesus and Moses listening to God on desert soil, and the sanctified children of God dressed in white linen ( $\operatorname{Rev} 3: 18 ; 7: 13 ; 19: 18)$ are all reimagined and emulated, to the extent that it is not possible to explain Masowe theology without examining the various ways of grounding biblical ideas so that they shape ways of thinking through the symbolism of ritual behavior. More important when it comes to the timing of this article, the spiritual quest for liberation also draws attention to a call for ecojustice from an African perspective. In a world where globalization is the main cause of poverty, oppression and climate change, there is something powerful about going to pray in the wilderness. ${ }^{17}$

Johane Masowe thus laid the foundations for an African conception of God suited to questions about the African believers who struggle for survival as if they are in the diaspora. Masowe Apostles now have an established culturally appropriate system of biblical "symbols, which acts to establish powerful, pervasive and long-lasting moods and motivations focused on being in the wilderness."18 In other words, Masowe Apostles produced a tradition of Christianity allowing believers to embody and dramatize their knowledge of the Biblical God.

Going outdoors to look for the margins of the cityscapes of Harare, Francistown, Johannesburg, Durban, Lusaka, Ndola, and Nairobi has produced the lived setting for the embodiment of knowledge about God for the Masowe Apostles. Old biblical imagery of a patriarchal God who liberates the victims of oppression and leads them to spiritual awareness is transformed here into the creator healer, in Gaian terms, of the fragmented social, physical, and psychological relationship with other creatures on earth. What has developed during the course of a hundred years of African Christians' wandering and praying in the wilderness is now part and parcel of the lived understanding of God that contains answers to questions about eco-theology in Africa. ${ }^{19}$ Although it would be just as easy to associate this God with the harshness of deserts and the margins of the landscape far away from cities using the English language, the use of the Shona word masowe here is culturally significant as it describes a church or ecclesiastical community but also the liminal places used to reach out to God in prayers for salvation.

My first attempt to introduce Masowe Apostles to an audience interested in addressing ecological problems is in an article called "An African Gospel of

\footnotetext{
17 My own observation.

18 Geertz, Interpretation, 90.

19 Mukonyora, "Women."
} 
Survival in an Age of Ecological Destruction." ${ }^{20}$ That also ends with a reference to Clifford Geertz and an invitation to engage in further studies on ways of instilling the values of the practice of Christianity in an era of climate change. Why? Because the encounter with religious traditions in which religion is a way of life has increased awareness of the need to shift from abstract ways of doing theology, especially now that the real problems of life on earth call for action. In this scenario, climate change also calls for the combination of anthropological methods of inquiry with traditional theological methods of investigating Christian texts, sacred, primary, and others.

Anthropology and theology thus come together in this exploration of Christianity in Africa. The Shona language spoken by Masowe Apostles corresponds with Bantu culture in which knowledge is transmitted orally, meaning that it is necessary to examine closely the ritual behavior needed to make the biblical God real. ${ }^{21}$ Millions of Africans are experiencing economic hardship, life threatening diseases like AIDS, cancer, colds, fevers, problems of unemployment, and other misfortunes caused by militant ways of keeping authoritarian regimes in power. Let us begin by examining how the official leaders of the Masowe Apostles movement agreed to give God of the wilderness his aura of factuality by producing the Gospel of God. ${ }^{22}$

\section{The Double Patriarchal God}

The Gospel of God refers to Baba (Father), sometimes Tenzi (Lord), terms used for God. The honorific, madzibaba, is generally used with first names to refer to boys and men as "fathers," especially at prayer meetings. The document entitled "The Calling of Baba Johane," speaking of the prophet and founder of the Masowe Apostles reads,

God then asked, do you know why you have been ill for so long? He (Johane) answered, 'I don't know Lord.' God said, 'You have been ill because of the sins which you have committed against me on earth since the day you were born.' Sixpence [nickname for Johane] was unconscious...We (his followers) were hearing his voice answering Jehovah from heaven...

20 Isabel Mukonyora, "An African Gospel of Survival in an Age of Ecological Destruction," Worldviews 14, no. 2-3 (2010): 171-184.

21 Mukonyora, "The dramatization."

22 Zimbabwe has been controlled by the same militant regime led by Robert Mugabe since 1980. Since I finished my fieldwork around January 2000 and left the country, the difficult human conditions have got much worse. 
while his body was lying before us...[then] we heard the spirit getting back into the body, making a sound like that of air being pumped into a bicycle. $^{23}$

This story is one of several in which "Baba Johane" is portrayed as sleeping, unconscious, or nearly dead, which is a little confusing in Shona where the term kufa (to die) is commonly used to describe different kinds of human suffering, including death. As observed by anthropologist Matthew Schoffeleers, Bengt Sundkler, and other scholars of religion in contemporary Africa, it was common for other prophets and healers in various parts of sub-Saharan Africa to associate suffering with spiritual gifts of n'anga whereby death - like suffering, feeling withdrawn from society, and sickness - is invoked in stories about individuals who are later recognized as healers, diviners, or spirit mediums. ${ }^{24}$ The Gospel of God is thus a good example of an African attempt to interpret the suffering and death of Christ. The stories of Johane Masowe, Johane Maranke (also popularly known as John the Baptist), Alice Lenshina from Zambia, Isaiah Shembe from South Africa, and Simon Kimbangu from Zaire, demonstrate that the religious imagination may be used to draw attention to the redemptive passage through life to death before healing the relationship with God takes place. ${ }^{25}$ In the story of Isaiah Shembe, the prophet illustrated his acceptance of the crucifixion by explaining a dream in which "he found himself surrounded by a rattling host of skeletons of the dead, making noise...and fell down in terror." When Shembe awoke, he was convinced that God had protected him from the forces of death and was sending him to spread the gospel. ${ }^{26}$

In short, we have in the Gospel of God a good example of a common practice of dramatizing knowledge about God by highlighting kufa (suffering and/or death).Victims of suffering thus embody knowledge to do with a powerful God who heals the sick and uplifts the poor, as the creator heals Mother Earth by sending rain to combat drought, for example. Experiencing healing through the power of the Holy Spirit is, in other words, a way of drawing attention to New Testament stories about Jesus performing miracles among the poor, not to mention preaching the famous Sermon on the Mount (Matthew 5, 6, and 7), which has become a live and direct message for Masowe Apostles. To make

\footnotetext{
23 "The calling of Baba Johane" in "Gospel of God."

24 Matthew Schoffeleers, "Folk Christology: The Dialectics of the N'anga Paradigm," Journal of Religion in Africa 19, no. 2 (1989): 157-183.

25 Richard Werbner, "The Suffering Body: Passion and Ritual Allegory in Christian Encounters," Journal of Southern African Studies 23, no. 2 (1977): 311-324.

26 Bengt Sundkler, Zulu Zion and Some Swazi Zionists (Uppsala: Oxford University Press, 1976), 184-185.
} 
sense of this live and direct way of proving that God exists, it was necessary for Johane Masowe, their founder, to experience kufa. In doing so, he brought the gospel closer to a culture destroyed by drastic social changes imposed by colonial regimes than the European missionaries who viewed the symbolic act of exact readings from the Bible as the way to establish powerful, pervasive, and long-lasting moods and motivations in Africans, thereby claiming authority to talk about God in Christianity.

During the 1930s Economic Depression, when Johane started preaching, he was often sick, unemployed, and preoccupied with feelings of total dependence on God. European missionaries may not always have been conscious of it, but they created the setting for the rise of oral traditions of Christianity in modern Africa. They developed a lived theology by building churches for their rituals, translating and telling stories from the Bible into Shona, insisting on modern African clothes and manners, and teaching reading, writing, and other technical skills associated with Western ideas of the successful spread of patriarchal Christianity in Africa. ${ }^{27}$ The prophet Johane Masowe thus lived in the shadows of a changing society of people being taught to view themselves as individual sinners as their Shona culture was replaced with Global Christianity as the framework for the growth of a gendered colonial discourse of morality. ${ }^{28}$ It is no surprise the passage from Gospel of God cited above refers to Sixpence and "a bicycle" in the context of a story intended to show the extent of God the Father's healing power. Bicycles were being manufactured as cheap transport for factory workers and postmen in Africa of the time. ${ }^{29}$ Although I never witnessed such a serious manifestation of the healing power of God through the Holy Spirit, I listened to one sermon after another stressing the fact that God of the wilderness has the power defeat Satan, conquer the forces of death, heal the sick, console the poor, and generally help believers deal with personal misfortunes. ${ }^{30}$ The "Calling of Baba Johane" is just one of several powerful

27 Isabel G. Antonio, Independent Churches Among the Shona (thesis, University of Edinburgh, 1989), 51-95.

28 Diana Jeater, Marriage, Perversion, and Power: The Construction of Moral Discourse in Southern Rhodesia 1894-1930 (Oxford: Clarendon Press, 1993). This is an excellent book on the moral discourse based on a lot of assumptions about Christianity as a patriarchal world religion.

29 Zimbabweans often laughed at me for riding a pink bicycle and wearing colourful cotton trousers to avoid being confused with men from the local factories. Although able to ride the bicycle for fieldwork, I needed to be discreet.

$30 \quad$ Although the words "suffering and healing" are used in the title of the book Isabel Mukonyora, Wandering a Gendered Wilderness (New York: Peter Lang Publishing Group, 2007), there is no talk about miracles, just healing in social and psychological senses. 
dramatizations of the power of the Holy Spirit that is part of the Trinitarian God of the Christian faith.

This way of talking about God is associated with patriarchal Christianity here because research has shown that only men dominate as official leaders of AICs, such as those mentioned above from Zimbabwe, South Africa, Zambia, and Zaire. As indicated, before they are recognized as preachers, healers and/or prophets, they show the power of God in their lives in the wilderness by talking about God in the masculine form using the Shona term Mwari (the high god)-Baba (Father). Male preachers talked about Mwari-Baba in sermons and, when presiding over healing ceremonies, some of them shout at Satan, pace up and down, wave their hands in the air, point their fingers, and push the sick to the ground to draw attention to either the gravity of the problem of sin and death, or the power of God entrusted to them by the Holy Spirit. A lot of these gestures are not of the sort commonly used by women to communicate their thoughts about God. God becomes embodied in male leaders of members of a Shona patriarchy whose power was otherwise shattered in the patriarchal Christian roots of African colonial modernity. ${ }^{31}$

Here is a typical example of the words often used to portray God. "MwariBaba created us men with gifts which women did not get from the beginning. Those gifts include leadership of the church, the homes for our male seed (children), and society in general...women must obey! That is God's own wish since creation."32 This excitable preacher went further; "Men are strong enough to do the work of Holy Spirit when it comes to the fight against Satan. Women were not made for the fight against Satan."33 Spontaneously, the women elders present at the prayer meeting concerned started to sing. Difficult though it was to follow the lyrics, it was obvious that they were songs expressive of the transcendent beauty of God and the hope that salvation would effectively highlight the limitations of sexism. Masowe songs, even those led by men, could be used to motivate and encourage mutual love and friendship among believers.

In the Shona past, songs were often used in the same way, to reconcile different opinions about problems of injustice or conflict. At funerals, marriage ceremonies, and the problem-solving meetings of elders, women would suddenly start singing songs to be taken as advice or warning about the need for justice,

31 Michael F. C Bourdillon, Where are the Ancestors? Changing Culture in Zimbabwe (Harare: University of Zimbabwe Publications, 1993).

32 Isabel Mukonyora, "Religion, Politics and Gender in Zimbabwe," in Displacing the State: Religion and Conflict in Neoliberal Africa, eds. John H. Smith and Rosalind I.J. Hackett (Notre Dame: University of Notre Dame 2012), 136-159. 
peace, and harmony. ${ }^{34}$ This creative way of making songs an alternative form of God-Talk in a contemporary world in which the majority of Africans believe in the idea of a biblical God, is easy to relate to the definition of religion used to explain the dramatization and embodiment of knowledge of which Masowe Apostles are known for spreading in Africa. At least, insofar as the burning questions one might ask of Christianity are addressed through the ritual behavior of the Masowe Apostles, who did not see any need to read the Bible as taught by European missionaries, Shona women use melody to create "verses" that correspond with their spiritual need to eradicate sexism among the children of God. Rather like announcing that one is reading the gospel and demanding silence just before the sermon in mainline churches around the globe, the women of the wilderness rely on the religious freedom to sing. The "verses" become a culturally appropriate way of inviting believers to stop what they are doing and concentrate on the fellowship of believers in the same transcendent God. Everyone is expected to pay attention to divine words of wisdom that come with these songs of the wilderness. They are called "verses" not necessarily because they are words taken directly from the Bible, but because the motivation to sing is inspired by the spiritual need to change the mood and motivation of male preachers who tend to sin during God-Talk - which is meant to be a theology of liberation - by sounding sexist and oppressive to women. ${ }^{35}$ Indeed, there is no doubt sexism is a problem among Masowe Apostles. Women use singing to remind men that the "God beyond the Father" loves all his children. ${ }^{36}$

During the 1930s when Johane was first arrested for preaching on the margins of the cityscape of Harare without a pass or license to preach from the colonial authorities, ${ }^{37}$ European missionaries would use the term Mwari-Baba to develop the lived understanding of God; this was rejected by Masowe Apostles as serving the interests of a British colonial regime responsible for the displacement and subjugation of Africans. The police who arrested Johane for

34 It was common for women to sing in public as a way of expressing their fear of bad husbands, something I noted whenever I attended marriage ceremonies or funerals. My own mother tongue is Shona.

35 In some groups, the men started to lead songs themselves, trying to impress women with their voices, rather like boys in a choir. This silenced some women, but not most elder women who were well versed in oral tradition.

36 Mary Daly, God-Beyond-the-Father (Boston: Beacon Press, 1973). This book looks for an answer to the problem of the reciprocal relationship of a patriarchal world to centuries of God-Talk in Christianity.

37 "Statement by Shonhiwa to Detective Bond (C.I.D.) in Salisbury," interpreted by Zakia, November 1st, 1932, S138/22, National Archives of Zimbabwe in Harare. 
preaching in the wilderness were conversant enough with the problem of oppression at the time of Jesus to recognize the mood and motivation of the founder of the Masowe Apostles. He was using biblical stories of oppression to address an African audience of Christians caught up in social changes causing the poor to migrate from rural areas to cities where it was crucial to find employment in a job market forced upon Africa through industrialization.

Johane made a connection between his personal feelings of marginality and displacement and the oppression of Africans loud and clear by dramatizing his suffering, death, and healing often enough for his followers to remember his theology. As a young man and preacher, Johane was inspired by John the Baptist, as well as Jesus who is also said to have walked through the wilderness surrounding the city of Jerusalem preaching and healing the sick. Insulted by the symbolism of Johane's behavior, the police beat him up, threw him in jail and, upon the prophet's release, mocked him, saying it was time for him to leave the city and return to Gandanzara (Land of Hunger), a rural homeland that encapsulated the whole problem of Europeans' seizing fertile land and pushing Africans to more barren areas. ${ }^{38}$ In this case, the agents of colonial oppression enforced the white male supremacist rule of excluding the poor from the city in a manner which strengthened Johane's resolve to preach about Mwari-Baba of the wilderness.

There are some interesting names for Mwari-Baba which suggest a variety of things about his nature relevant to the perspective of theological discourse in which knowledge about God as male first finds bold expression: Mwari as he who rules the heavens is called Nyadenga; Mwari as he who is at the apex of creation is Wokumusoro (the one above); and he is also Musiki (the maker of things), Musikavanhu (the creator of humans), and Muzivazvose (all knowing). For the sake of brevity on this matter of divine attributes, which male preachers presume to go hand in hand with biblical language referring to Mwari-Baba, the latter could also be called Mutangakugara (the first to exist). Although European missionaries talked about Mwari as Baba to help converts to Christianity realize the difference between Mwari with a female dimension and the father figure and the Supreme Being, the patrilineal ancestor system of the Shona benefitted from the added use of male imagery to describe Mwari as an omnipotent "high god." ${ }^{39}$ Given the hierarchical social order that put men in

\footnotetext{
$38 \quad$ Ibid.

39 Written with lower capital letters, the reference "high god" was used by Europeans to characterize Mwari. However, when it comes to Mwari, Europeans had no problems using Mwari with the capital letter " $\mathrm{M}$ " to designate Mwari as the same Supreme Being as the biblical God.
} 
charge of women, children, and whole territories, it suited Masowe Apostles to call God the Father, Mwari-Baba in Shona.

In "The Calling of Baba Johane," 1932 is year that Johane Masowe started preaching. Following the arrest described above, Johane Masowe asked his first followers, "Did you hear me talking to my Father?" ${ }^{40}$ In other words, it was not enough to say "Jesus the Son of God." Johane developed a personal view of God as his own Father (Baba). The New Testament was a source of this knowledge about God as a deity whose love is as direct as it is personal. In "The Descent of Baba Johane," the immediate followers of the prophet clearly viewed themselves as living witnesses to a story of redemption in which the Bible was invoked. The text reads, "It happened one day that Johane Masowe said, 'I am going to my father...it was his habit that when he went to his Father, he would lose consciousness..."11 In other words, the image picked by the founder of the Masowe Apostles to explain the popularity of the term Mwari-Baba, is that of God as a father figure. The other Shona patriarchal term used to refer to reinforce the image of God-the-Father is Tenzi, rather like "Lord" in New Testament Greek. In his "calling" or conversion experience, Johane refers to God as Lord when he begins to see that human disobedience and the burden of sin against God is the root cause of human suffering. ${ }^{42}$ Then he responded to God's calling by doing the appropriate thing, a course of action found in millions of other conversion stories in Christianity. He asked for the mercy of his Father - or "Tenzi," in the sense of someone who controls a territory and protects the families who live on it. In Daneel's study of the Rozvi, one of up to eight groups of Shona people known through dialects spoken in Zimbabwe. The Rozvi confederacy consisted of loosely affiliated vassal states stretched over a vast territory. Rozvi dominance was not exclusively to do with military superiority, but also the result of the widespread belief that the Shona High God himself had called the Rozvi monarchy into being. ${ }^{43}$

$40 \quad$ "The Calling of Baba Johane," by Samson Mativera, dated October 1st, 1932, cited in Clive Dillon-Malone, The Korsten Basketmakers: A study of the Masowe Apostles, an indigenous African Religious Movement, appendix B32 (Manchester: Manchester University Press, 1978), 145 .

41 Ibid.

42 "Descent of Baba Johane on Mount Marimba," written by General Secretary, Nairobi (date unknown), cited in Clive Dillon Malone, The Korsten Basketmakers: A study of the Masowe Apostles, an indigenous African Religious Movement, appendix B64 (Manchester: Manchester University Press, 1978), 151.

43 Martinus Daneel, God of the Matopo Hills: An Essay on the Mwari Cult in Rhodesia (Hague: Mouton and Co., 1970), 19; Terence O. Ranger, Aspects of Central African History (London: Heinemann, 1968), 112-113. 
The reference to God as Tenzi, or familial guardian of African lands, endeavors to communicate the Lordship of Christ associated with the return of Christ in the patriarchal culture of the New Testament. In the Standard Shona dictionary produced by the Catholic priest, Fr. Hannan S.J., the term Tenzi designates the proprietor of a dunhu (territory) or a patrilineal spirit. This lineage spirit has power to rule, defend, and protect territories from harm. ${ }^{44}$ As van der Merwe put it, Mwari among the Shona is concerned with the "welfare of the tribe." Mwari thus protected the life of members of the Shona patrilineage. ${ }^{45}$

When Johane Masowe cries out, "You are the Lord...Have mercy on me Lord," in Shona, he gives meaning to a traditional way of thinking about God as a father figure who created and rules the world with male leaders of lineages making sure that God is obeyed in the Bible and his Shona-speaking target audience at the same time. No wonder Johane Masowe found it easy to travel throughout central Africa, leaving behind members of the wilderness church led by groups of men whose claim to authority was the belief that Mwari is powerful and omnipresent, only this time he was addressing victims of colonial oppression. It became Johane Masowe's personal duty before God to warn people "to seek righteousness if they wished to survive the mighty judgement to befall the earth." 46

Masowe Apostles continue to turn human suffering into the reason for prayer in a world where disempowered members of a male dominated society were accustomed to express their hope for liberation as male leaders first. ${ }^{47}$ For the women who have always attended Masowe prayer meetings as majority believers - and whose own belief in God the Father corresponds more with the concept of a God who loves all his children, and liberates all victims of oppression, male or female, as long as they are poor, sick, and experiencing other misfortunes to do with life in the margins of the global village - male dominance presents a unique challenge. Despite the prevalent use of the metaphor

44 There is a religious dimension to the idea of a "double patriarchy" studied by Elizabeth Schmidt with the history of Zimbabwean society in mind. See Elizabeth Schmidt, Peasants, Traders and Wives: Shona Women in the History of Zimbabwe, 1870-1939 (London: James Currey, 1992), 14-42.

45 Martinus Daneel, Old and New in Southern Shona Independent Churches (Leiden: Mouton Press, 1971), 88-90.

$46 \quad$ Ibid., 151.

47 See Isabel Mukonyora "The dramatization" on Masowe Christology. Johane hints at the belief in God's continuing revelation by sending messengers of God like the prophets, Jesus and Johane Masowe. The idea of a Black Messiah figures in AICs such as the Kimbangu Church, originating in Congo, and Isaiah Shembe, originating in South Africa, comes from similar cultural roots with a lived understanding of God the Father being revealed among humans. 
for God as the Father and men as official leaders of the church of the wilderness since the beginning, we should make a note of the sacred role of women at this stage. Women sing the "verses" as a medium of communicating a perception of God inspired by a much more radical quest for liberation for all children of God.

\section{$3 \quad$ God the Father through Women's Eyes}

As indicated above, women are not passive recipients of knowledge about God during prayer. The sexist behavior of the male preachers oftentimes leads women to interrupt sermons by singing choruses that draw attention to ways of thinking about God the Father differently, as a deity of love, peace, justice, and healing on earth. Anyone who is attracted to the wilderness in the hope of experiencing divine compassion through the gift of healing and the treatment of the children of God as equal will understand the need for more research on the lived understanding of the Masowe concept of God. As the majority members of the Masowe Apostles, without whom there would be no vibrant wilderness church, Shona women and children should be viewed as important agents of knowledge, especially when it comes to rituals at which men are mostly, if not always, outnumbered by women and the children they bring to the wilderness.

In this context of lived Christianity, we do not have to read St. Augustine to be sure that Masowe Apostles have a correct understanding of Western orthodox doctrine. The need to diversify the language that references God is made apparent in all sorts of ways, starting with the fact that women have always had an embodied knowledge to do with traditional roles in which giving birth was a symbolic act which corresponded with God-Mwari as the source of life on Mother Earth. In the Shona past, it was women who farmed the land and acted as stewards of the earth as well as cared for children and the homestead. Although men viewed themselves as the lineage heads of the family and owners of the land, they were taking advantage of women. ${ }^{48}$ for men to bear in mind when exercising authority and making claims about representing God on earth. Without male preachers going out of their way to add the word Baba to the name of God (Mwari) this chapter would begin here, with ideas of an ecological deity who gives hope to all believers in God of the wilderness. After all, the "verses" aside, the term "masowe" does not merely describe harsh or wild surroundings; it also refers to sacred sites for prayer. Rather than being places 
that might fill one with dread, Masowe Christians count on Mweya Mutsvene (the Holy Spirit) to make sites for prayer sacred. ${ }^{49}$ It is even taboo to question any woman who decides to start singing the "verses" in the middle of sermons. Even though the goal is a positive one of encouraging preachers to address questions about life on earth in moving ways, male preachers must stop to let the Holy Spirit do its work of revealing the nature of Mwari-Baba as the God of love for all the vanquished. ${ }^{50}$

In short, the lived concept of God of the wilderness examined above is incomplete. The God in question is simultaneously revealed by the Holy Spirit, and the Holy Spirit does not discriminate between the children of God, including real children brought to the wilderness for prayer. ${ }^{51}$ To complete this discussion about the Masowe concept of God, therefore, one must bear in mind the fact that women and children far outnumber men at most if not all Masowe Apostles' gatherings in the wilderness. This is despite the official roles of men and the official language about God found in The Gospel of God, and witnessed during fieldwork. Masowe ritual activities are not the same without large numbers of women and children. Indeed, most of the sins described are blamed on women - they are deprived creatures, lacking a sense of morality. As McCulloch found in his study of archival documents written by European missionaries who supported the colonial treatment of Shona women as subordinates of their fathers, husbands and uncles, the best place for the Shona woman was at the rural margins of the country with missionaries providing education on how to develop good morals and obedience. ${ }^{52}$ In other words, Mwari-Baba, as seen through women's eyes, raises questions about the nature of the Trinity in Christian God-talk. Insofar as this is a discussion of a system of symbolic actions describing the fundamental theological ideas of the Masowe Apostles shaped by the Gospel of God, God of the oppressed is coterminous with the aura of factuality surrounding God as the Father of Jesus as represented by the female adherents of the faith at prayer. Acting through what Masowe women believe to be the power of Holy Spirit to discern the will of God, the potential for the development of a distinctively African eco-theology is possible..$^{53}$

\footnotetext{
49 "National Public Radio interview with Krista Tippett."

50 Some songs are happy while others are a way of giving sound advice otherwise lost in dramatizations of male authority.

$5^{1} \quad$ See book cover of Mukonyora, Wandering.

$5^{2}$ Jock McCulloch, Black Peril, White Virtue (Bloomington: Indiana University Press 2001), 128-166.

53 Mukonyora, "The dramatization." This article is about Johane's dramatization of the life and death of Jesus and the cultural significance of making salvation a matter of having the same hope for salvation as Christ had at his death. The doctrine of the Trinity is not a
} 
Moreover, the Gospel of God recognizes and makes it an official role of women to represent the divine wisdom of the Logos. ${ }^{54}$ Not only did a woman communicate Mwari's wishes as his Izwi (Voice) in the Shona past, the most popular name used during prayers for rain, good harvest, and the fertility of women as mothers and farmers in charge of agrarian household economies, was Mbuya (the Great Mother). Even more interesting to note here, in terms of the Shona background to the writing of the Gospel of God, is the ritual function of women devotees as symbols of the living voice of Mwari. Hence, another popular name for Mwari is Dzivaguru (the Great Pool), a way of describing a shrine for Mwari as the great womb of creation from which emanates the Izwi of God. Hence, one finds to this day a shrine located inside a cave in Matonjeni containing a pool which is a symbol of the Divine Mother' womb, with amniotic fluids that are the fons et origo of life. ${ }^{55}$ All this demonstrates that Shona people already have terms with which to translate the idea of the Holy Spirit from the paraclete (Greek for helper or advocate) into a language about zvakazarurwa (the revealed word) in which prevail feelings of awe and total dependence on a transcendent God, source of all life in the universe. ${ }^{56}$

Clearly the term Mwari-Baba does not fully capture the meaning of God of the wilderness until we consider the large numbers of women who attend prayer meetings confident they have the paraclete on their side. The point made earlier that Masowe Apostles take us beyond God the Father to another realm of life and to direct experiences of the Holy Spirit certainly furthers our understanding of the Masowe concept of God once we are prepared to test Clifford's definition of religion with facts about the ritual behavior of Masowe Apostles.

It seems appropriate to end this discussion with proof of the special interest taken in the Scriptures of knowledge that comes direct from God. Revelation 7:9-10 reads,

After this I looked, and there before me was a great multitude that no one could count, from every nation, tribe, people and language, standing before the throne and before the Lamb. They were wearing white robes and

problem for Masowe Apostles, unless Western theologians insist on making it an intellectual matter instead of a formula of faith.

54 Daneel, God of the Matopos Hills.

55 Herbert Aschwanden, Karanga Mythology (Gweru: Mambo Press, 1989), 13. This is an excellent book to read on Shona ideas about God-Mwari as male, female and, simply transcendental beauty.

56 Being immersed in mother nature with questions about the meaning and purpose of life on earth as embodied knowledge goes well with the lived understanding of God. 
were holding palm branches in their hands. And they cried out in a loud voice: 'Salvation belongs to our God, who sits on the throne, and to the Lamb.'

As a participant observer of a Masowe theological discourse whose participants always dressed in white robes, sat shoeless on the dusty ground, and treated the sacred wilderness as a place to share fundamental beliefs, it was interesting to meet so many strong women prepared to uphold justice at prayer meetings. In fact, it would be a mistake to end this chapter with what the male preachers say about God. The idea of God perceived as an ecological deity whose presence is given expression by women at ritual thus completes the dramatization, performance, and embodiment of knowledge among Masowe Apostles.

Finally, it seems appropriate to acknowledge Richard Werbner's pioneering work on Masowe symbolism. Werbner argued ten years before my gendered encounter with Masowe Apostles that they leave us with "an argument of images: From Zion to the Wilderness in African cultures. ${ }^{57}$ Among the earliest Christians, of whom were many women, the latter sought liberation from poverty, disease, and general misfortunes that came with oppression in the patriarchal world of the Greco-Romans. The Roman Empire created a spiritual crisis by seizing the "The Promised Land" or Zion. As stated above, the spread of Christianity in colonial Africa led to the rise of churches responding to another spiritual crisis, this one caused by social change and acts of environmental degradation associated with industrializing society in Africa. When it comes to approaching theology in terms which are anthropological and based in oral traditions, Masowe Apostles present an intellectual challenge for anyone who wishes to talk about Global Christianity and develop theological ideas to match its contemporary growth. Given the continued spread of the Masowe Apostles in Africa, it is time to draw attention to an environment largely destroyed by industrialization, urbanization, and the abuse of people, land, animals, and plants to create a vast modern Africa whose God of the wilderness calls for further investigation, with special attention to environmental ethics. ${ }^{58}$

57 Richard Werbner, "The argument of Images: From Zion to the Wilderness in African churches," in Theoretical Exploration in African Religion, eds. W. van Binsbergen and M. Schoffeleers (London: Routledge \& Keegan Paul, Plc. 1985), 253-286.

58 Isabel Mukonyora, "An African Gospel." As I prepare a monograph of Masowe Systematic Theology for Climate Justice, I have been looking for the opportunity for publications like this one. 


\section{References}

Antonio, Isabel. G. Independent Churches Among the Shona. Thesis, University of Edinburgh, 1989 .

Aschwanden, Herbert. Karanga Mythology. Gweru: Mambo Press, 1989.

Bourdillon, Michael F.C. Where are the Ancestors? Changing Culture in Zimbabwe. Harare: University of Zimbabwe Publications, 1993.

Daly, Mary. God-Beyond-the-Father. Boston: Beacon Press 1973.

Daneel, Martinus. God of the Matopos Hills: An Essay on the Mwari Cult in Rhodesia. The Hague: Mouton and Co, 1970.

Daneel, Martinus. Old and New in Southern Shona Independent Churches. Leiden: Mouton Press, 1971.

Dillon-Malone, Clive. The Korsten Basketmakers: A study of the Masowe Apostles, an indigenous African Religious Movement. Manchester: Manchester University Press, 1978.

Engelke, Matthew. A Problem of Presence: Beyond Scripture in an African Church. Berkeley: University of California Press, 2007.

Geertz, Clifford. Interpretation of Cultures. New York: Basic Books,1973.

Gutiérrez, Gustavo. A Theology of Liberation: History, Politics and Salvation. Translated by Caridad Inda and John Eagleson. Maryknoll, NY: Orbis Books, 1988.

Jeater, Diana. Marriage, Perversion and Power: The Construction of Moral Discourse in Southern Rhodesia 1894-1930. Oxford: Clarendon Press, 1993.

McCulloch, Jock. Black Peril, White Virtue. Bloomington: Indiana University Press, 2001.

McFague, Sallie. A New Climate for Theology: God, the World, and Global Warming. Minneapolis: Fortress Press, 2008.

Mukonyora, Isabel. “The dramatization of Life and Death by Johane Masowe." Zambezia 25, no. 2 (1998): 191-207.

Mukonyora, Isabel. The complementarity of male and female imagery in Masowe Theological language. Doctoral thesis, Oxford University, 1999.

Mukonyora, Isabel. "Women of the African Diaspora Within." In Women and Religion in the African Diaspora: Knowledge, Power and Performance, edited by R.M. Griffiths and B.D. Savage, 59-80. Baltimore: The John Hopkins University Press, 2006.

Mukonyora, Isabel. Wandering a Gendered Wilderness. New York: Peter Lang Publishing Group, 2007.

Mukonyora, Isabel. "An African Gospel of Survival in an Age of Ecological Destruction." Worldviews 14, no. 2-3 (2010): 171-184.

Mukonyora, Isabel. "Religion, Politics and Gender in Zimbabwe." In Displacing the State: Religion and Conflict in Neoliberal Africa, edited by J.H. Smith and R.I.J. Hackett, 136-159. Notre Dame: University of Notre Dame, 2012. 
"National Public Radio interview with Krista Tippett" http://www.onbeing.org/ program/sacred-wilderness-african-story/169/audio - February 22, 2007.

Pope Francis. Laudato Sí: On Care for Our Common Home. Encyclical Letter, 2015.

Ranger, Terence O. Aspects of Central African History. London: Heinemann, 1968.

Schmidt, Elizabeth. Peasants, Traders and Wives: Shona women in the History of Zimbabwe. London: James Currey, 1992.

Schoffeleers, Matthew. "Folk Christology: The Dialectics of the N'anga Paradigm." Journal of Religion in Africa 19, no. 2 (1989): 157-183.

"Statement by Shonhiwa to Detective Bond (C.I.D.) in Salisbury." Interpreted by Zakia, November 1, 1932, S138/22. National Archives of Zimbabwe in Harare.

Sundkler, Bengt. Zulu Zion and Some Swazi Zionists. Uppsala: Oxford University Press, 1976.

Werbner, Richard. "The Suffering Body: Passion and Ritual Allegory in Christian Encounters." Journal of Southern African Studies, 23, no. 2 (1977): 311-324.

Werbner, Richard. "The argument of Images: From Zion to the Wilderness in African churches." In Theoretical Exploration in African Religion, edited by W. van Binsbergen and M. Schoffeleers, 253-286. London: Routledge \& Keegan Paul, Plc. 1985. 